\title{
The Contribution of Micro Finance Institutions to Households Welfare: A Case of Finca And Pride in Iringa Tanzania
}

\author{
Hadija Matimbwa \\ Ruaha Catholic University- Tanzania hadija.matimbwa@gmail.com \\ Theobald Kipilimba \\ Ruaha Catholic University- Tanzania
}

\begin{abstract}
This study assessed the contribution of microfinance institutions to household welfare in Iringa Municipality. More specifically, the conditions set by MFIs in the entire process of granting credits to borrowers were analysed. The study further assessed the capacity of loan repayment among borrowers, examined the contribution of microfinance institutions to household businesses, and examined the household welfare situation prior to and upon accessing microfinance support. A cross-sectional research design with a mixed method approach was adopted. Questionnaires (constituting both open and closed ended questions), interview, and FGDs methods of data collection were used to obtain data from a sample size of 91 respondents. Quantitative data were analyzed using descriptive statistics, while the content analysis technique was employed in the analysis of qualitative data.

Controversial findings revealed that while some households' welfare improved upon loan investment into businesses, the welfare of others only worsened upon loan repayment. Furthermore, some conditions placed by MFIs such as interest rates and the requirement of collateral were some of the leading hurdles experienced in the process of securing MFIs loans. It was further revealed that the loan repayment capacity of beneficiaries is greatly challenged by the monthly and weekly instalment duration. The duration seems to be too short for them to comply. It was concluded as per findings that MFIs contributions were adequate in improving their loan beneficiaries' household welfare. It was also conclusive that some MFIs conditions are a significant barrier to the loan acquisition process thus; it is recommended that MFIs should consider revising some of the conditions observed as the most limiting to clients. MFIs should also provide credit according to their clients' demand in order to invest in LGAs that are more productive.
\end{abstract}

Keywords: Household welfare, Microfinance Institutions

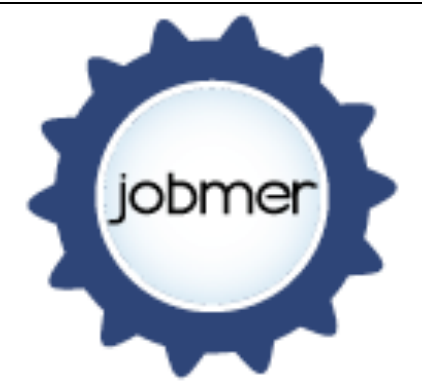

Journal of Business Management and Economic Research Vol.2, Issue.6, 2018 pp.1-10

Doi: 10.29226/TR1001.2018.37 
Hadija Matimbwa - Theobald Kipilimba, 2018, Vol.2, Issue.6, pp.1-10

\subsection{Background to the study}

Microfinance is defined as a set of innovative and alternative financial services to the poor who lack access to formal financial institutions (UNDP, 2003). Microfinance provide services like micro credit, micro serving, and micro insurance to individuals, groups, and institutions, NGO's for the purpose of development (Doocyet al., 2003). Historically, micro financing can be traced back to the mid 1800s, when theorist Lysander Spooner authored the benefits of small credits to entrepreneurs and farmers as a means to combat poverty (Roodman, 2011). The original intension of Microfinance institutions was financing poor communities towards sustaining their living, constructing better housing facilities, acquiring basic education, and fighting against poverty. The institutions were introduced to serve the financial needs of the unserved or underserved groups of people in the community as a means of realising development (Chijoriga and Cassimon, 2000).

Over the years, East African countries including Tanzania have witnessed the mushrooming of organizations providing financial services to clients to include; loans, saving plans, insurance, and payment transfers (Littlefield et al., 2003). Micro finance institutions provide innovative and effective channels of economic activities by investing in various fields aimed at improving health, education, and borrowers' living standards. The institutions play a pivotal role in increasing consumption capacity and income levels, the race for quality education, better quality of life, and health, all of which require a raise in income levels and expenditure (Kane, 2011).

The government of Tanzania has been implementing financial sector reforms since 1991. The aim was to put in place competitive, efficient, and effective financial systems (Rubambey, 2002). The principal elements of the financial sector reforms were liberalization of interest rates, the restructuring of state owned financial institutions, the establishment of private banks, strengthening the Bank of Tanzania's role in regulating and supervising financial institutions and strengthening of Savings and Credit Cooperative Societies (SACCOS) as grass root providers of financial services (Microned, 2006). The reforms commenced with the enactment of the Banking and Financial Institutions Act of 1991. This permitted the establishment of private sector-owned banks. It further provided a structure for regulation and supervision of the financial sector (World Bank, 2003). Along with banking de-regulation, the Cooperative's Act of 1991, authorized the structuring of the Cooperative movement and permitted the establishment of the Savings and Credit Cooperatives (SACCOs). The aim was to provide services, credit to low income earners, and consequently improve their welfare (URT, 2000).

The government of Tanzania established the National Microfinance Policy as a means of reducing poverty and spur economic growth in 2000 (MoF, 2000) and was implemented in 2001 (BOT, 2001). The focus of the policy was the provision of financial services to low-income households and their enterprises both in rural and urban areas (Rubambey, 2002). The policy facilitated Non-Governmental Organizations (NGOs) in commencing micro-finance operations in Tanzania (Msambichaka et al.,2000). For instance, the government in an effort to provide micro-finance services to people (REPOA, 2006) established the National Micro-finance Bank (NMB).

Microfinance institutions play a critical role in eradicating extreme poverty as envisaged in the Millennium Development Goals (goal number one). The goal was to ensure that the proportion of people living in extreme poverty globally declined by half by the turn of 2015(UN, 2009). MFIs enhance development effectiveness by contributing to poverty reduction, increased social and economic development, social empowerment, and community participation, school attendance of children, Economic prosperity, and household welfare (Ibid). Welfare is mostly 
thought of as a dynamic process that avails people a sense of how their lives are going, through the interaction between their circumstances, activities and psychological resources or mental satisfactory conditions of existence, such as access to better health and education, food security, household consumption, and expenditure (ADB, 2007).

Household Welfare refers to the socio-economic indicators of a given group of people living in the same compound with a common source of income (Estes, 2004). Increasing people's income through micro credit, which leads to household welfare improvement, has been the target of financial institutions. Such effort has been undertaken institutionally although they have proved both futile and successful in the improvement of household welfare at various extents. It is upon such a background that this study was undertaken to investigate the contribution of micro finance institutions to household welfare in Iringa Municipal.

\subsection{Literature Review}

\subsubsection{Theory guiding the study}

\section{The Welfarist theory}

Adam Smith (Aidukaite, 2009) developed the welfare theory. The theorist created the invisible hand idea that became one of the most fundamental equilibrating relations in economic theory; the equalization of rates of returns as enforced by a tendency of factors to move from low to high returns through the allocation of capital to individual industries by self-interested investors. The self-interest will result in an optimal allocation of capital for society. Directly quoted, Adam asserts that: "Every individual is continually exerting himself to find out the most advantageous employment for whatever capital he can command. But the study of his own advantage naturally, or rather necessarily leads him to prefer that employment which is most advantageous to society". Adam further postulated that what is true for investment is true for economic activity in general. "Every individual necessarily labours to access basic necessities in life (well-being). The theory advocates that the lack of well-being translate to poverty. Both government and non-government organizations are therefore agued to develop strategies and instruments such as landing institutions in order to improve the poor people's well- being.

The Welfarist theory views microfinance as one of the most effective tools for combating poverty and realizing a sustainable life; the theory supports the idea of subsidizing microcredit programs in order to lower the cost of operating microfinance institutions to in turn lower loan interest rates (Morduch, 2000). The performance of MFI's is measured through household studies which focus on individuals living standards; number of saving accounts, number of loans, productivity improvement, incomes, capital accumulation, social services such as education and health as well as food expenditures (Brouwer et al., 2005). Welfarist is of the assumption that MFIs can achieve sustainability without the institutionalist definition of selfsufficiency (Tsuchiya et al., 2005).

They further argue that gifts for instance subsidies from donors serve as a form of equity, and as such, donors can be viewed as investors. Unlike investors who purchase equity in a publicly traded firm, MFI donors do not expect to earn monetary returns. Instead, these donor-investors realize an intrinsic return. These donors can be likened to equity investors who invest in socially responsible funds, even if the expected risk-adjusted return of the socially responsible fund is below that of an index fund. These socially responsible fund investors are willing to accept a lower expected return because they also receive the intrinsic return of not investing in firms that they find offensive (Robinson, 2001). Moreover, the theory argues that credit is provided to poor borrowers below market interest rates in order to reach the extremely poor to 
help overcome poverty and empower them. Welfarist theory focuses on credit as a poverty reduction tool. The performance of Commercial banks is rated using assets base, number of performing loans and size of the loan book, income, and corporate social responsibility such as education, health, and humanitarian activities undertaken by financial institutions in improving household welfare (Ibid). This theory is helpful in assessing the borrowers' capacity in meeting MFIs conditions and furthermore, the theory is helpful in assessing the use of credit in improving borrowers' household welfare.

\subsection{Empirical Literature Review}

\subsubsection{Conditions set by MFIs in the entire process of granting credits to borrowers}

Financial institutions impose several conditions during the process of granting loans, conditions such as collateral, which refers to a borrower's pledge of specific property to a lender to secure repayment of a loan (Yunus, 2001) is perhaps the most common condition. Operation of a legal business is another condition normally checked in the early stages of loan processing. Legality of the business is important for the contract and also to ensure that microfinance are keen to social responsibility requirements, that is desist from supporting illegal businesses (Pereira and Mourao, 2012). The guarantor is another important condition so that in case the borrower defaults, the guarantor can be contacted to help follow up with the client.

\subsubsection{The capacity of loan repayment among the borrowers}

The main aim of microfinance is to provide funds for micro business investment that are expected to increase household income and hence improve livelihood. However, most borrowers misappropriate loans to food, shelter, and clothing to meet their basic needs rather than the intended investment. As Bayang (2009) put it, at the time of loan disbursal, the poor borrowers are pre-occupied with pressing economic problems ranging from shortage of food, lack seedlings, and medical bills among others, a practice which renders loan repayment difficult. Gebeyehu (2002) conducted a case study of factors attributed to loan defaulting among private borrowers financed by Development Bank of Ethiopia Zway Branch. It was revealed that having an alternative source of income, education, experience in a related economic activity prior to securing a loan and engaging in an economic activity other than agriculture enhance successful loan repayment. However loan diversion, being a male borrower and extending the loan repayment period are undermining factors of the loan repayment capacity of projects. Mohamed and Shariff (2013) further studied the determinants of repayment performance of microfinance programs in Malaysia using the individual lending approach. Findings revealed that gender, business experience, education level, distance, or accessibility of the market place; total loan size and transaction costs have a positive coefficient to repayment performances. On the other hand, the age, religion, total income, business sector, business status, year of establishment, business area, total sales, loan type, repayment schedule, repayment period and loan monitoring have a negative coefficient between the delinquent and good borrowers.

\subsubsection{The contribution of microfinance institutions to household businesses}

Microfinance offer services to individuals and groups in a collective effort to improve their entrepreneurial skills by accessing affordable capital to develop their businesses through granted loans. Priority is given to micro enterprises, self-employment activities, and household enterprises i.e. MFI loans assist household borrowers in establishing business start-ups (Rutashobya, 2001).

According to Chestnut (2010) borrowers, use secured loans to initiate businesses such as purchasing wholesale goods to resell in markets, creating and selling crafts, farming, and other 
activities. The profits they earn allow them to repay the loan, make a living, and generally improve their living conditions. Ohri (2004) argues that while microfinance provides the poor with credit access to engage in income generating activities, loans secured are appropriated in increasing assets, including permanent houses or savings accounts, offering recourse during hard times and consumption especially on food, nutrition, and education.

Kuzilwa (2002) studied microfinance services In Tanzania and examined the role of credit in generating entrepreneurial activities. Findings revealed that the output of enterprises increased following credit access. It was further observed that enterprises whose owners received business training and advice performed better than their counterparts who lacked the same. It was recommended that an environment should be created where informal and quasi-informal financial institutions can continue to be easily accessed by micro and small businesses.

\subsection{Methodology}

This study was conducted in Iringa Municipality using the cross-sectional survey method where data was collected at a single point at a time from selected loan officers and borrowers. Two microfinance institutions in Iringa municipality were purposively sampled to include; PRIDE and FINCA. Ninety-one (91) respondents from whom data was collected through questionnaire, FGD, and interview informed the study. While quantitative data were analyzed descriptively, qualitative data were analyzed in accordance with common themes identified and by quoting the exact words spoken by interviewees and focus group discussants.

\subsection{Results}

\subsection{Demographic Information}

Table 4.1 Respondents' Profile

\begin{tabular}{llll}
\hline & Value & Frequency & Percentage \\
\hline Age & $18-27$ & 21 & 23.1 \\
& $28-37$ & 45 & 49.5 \\
& $38-47$ & 22 & 24.2 \\
& 48 and Above & 03 & 03.3 \\
\hline Level of Education & No Formal Education & 02 & 02.2 \\
& Primary Education & 31 & 34.1 \\
& Secondary Education & 48 & 52.7 \\
& College/University & 10 & 11.0 \\
\hline Loan experience & Once & 09 & 09.9 \\
& Twice & 15 & 16.5 \\
& Thrice & 39 & 42.9 \\
& More than 3 Times & 28 & 30.8 \\
\hline Total & $\mathbf{9 1}$ & $\mathbf{1 0 0}$ \\
\hline
\end{tabular}

Source: (Field Data, 2018) 
Data presented on table 4.1 above reveals that $49.5 \%$ of respondents were youths aged between 28 - 37 years old. The table further depicts that the majority of respondents $(52.7 \%)$ had obtained secondary school education, while $34.1 \%$ had primary school education. This indicates that credit was offered to respondents who have better knowledge about micro loans, the role of credit, benefits, understand the procedures of obtaining credit and meeting repayment obligations. The table also portrays that $42.9 \%$ of respondents had secured loans at least thrice whereas $09.9 \%$ had secured loans only once. This indicates that the majority of respondents had sufficient experience with financial institutions and in the right position to share their opinion regarding the impact of MFI's on their household welfare.

\subsection{Conditions Set by MFI’s in Granting Credits to Borrowers}

As presented on figure 4.1 below, the following conditions should be fulfilled by borrowers prior to securing loans from FINCA and PRIDE Tanzania;

Figure 4.1 Conditions set by MFIs in granting Credits to Borrowers

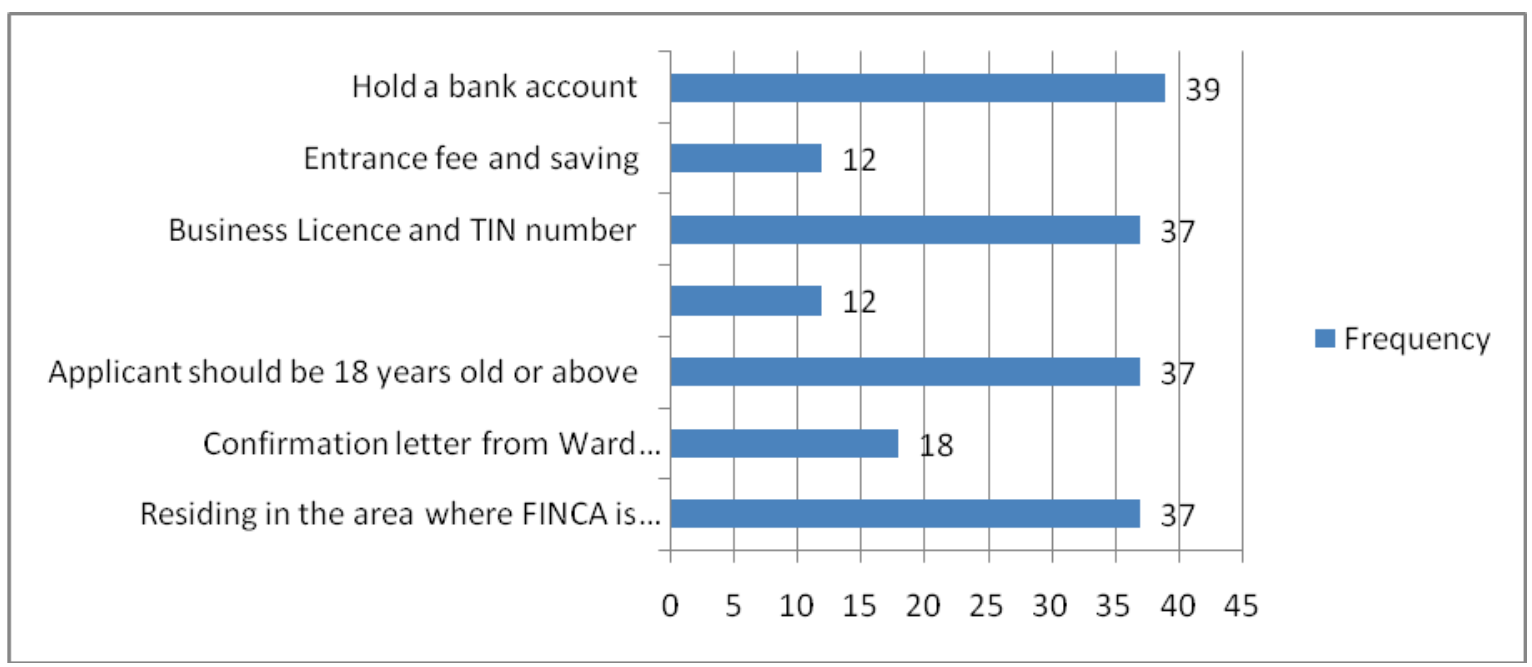

Source: field data (2018)

As presented on figure 4.1 above, the majority of respondents (39) admitted that possession of a bank account is one of the key requirements for obtaining a loan. Moreover, 37 respondents stated that residing in close proximity to FINCA/PRIDE offices, holding a business licence/TIN number and having attained the age of 18 years and above were also part of the criteria for securing a loan. Moreover 18 percent of the respondents stated that a confirmation letter from Ward Executive Officers was a requirement whereas 12 respondents agreed that entrance fees/saving as well as possession of viable income generating activities were required. The findings of the current study are in line with those from one study by $\mathrm{Ng}^{\prime}$ ana (2013) who examined the contribution of microfinance institutions in the development of small enterprises, a case of Ilala Municipality. The findings revealed that permanent location, guarantor, and high interest rates were the main challenges hindering small enterprises from accessing loans.

\subsection{The Capacity of Loan Repayments among Clients}

\section{Ability to repay loans on time by clients}

It was found that $78 \%$ of respondents were unable to promptly repay their loans as revealed in both institutions. This was also noted during the FGDs as one discussant directly stated; 
"...It is very difficult to repay loans on time as sometimes the business does not bring the desired results." On the same note, one loan officer concurred with the clients that; "For most clients, prompt loan repayment is always an uphill climb. The biggest problem is the business one is engaged in. They fail to raise the money on time which hinders their chances of obtaining loans when next requested..."

One borrower also stated;

..."prompt loan repayment is a big challenge for the majority of us. For example in my institution, we repay loans on a weekly basis which is a challenge and sometimes we pay late because a week is insufficient for accumulating enough money for loan repayment...".

Majority of respondents (92\%) revealed that the following factors affected their loan repayment capacity to include; high interest rates, short payback period, and the natures of economic activities borrowers engaged in.

\subsection{The Contribution of MFIs towards Households Businesses}

Findings revealed that all respondents who were loan beneficiaries from the two MFI's secured loans for business purposes. It was further revealed that 46 respondents $(50.4 \%)$ used their loans for improving their existing businesses, while 45 respondents $(49.6 \%)$ used their loans to increase business inventory. This implies that borrowers used loans to expand their businesses that is, engage in income generating activities and investment as capital increases. It was also found that these businesses were regarded as employment and supplemented family income through the profits earned. The profits allowed borrowers to repay loans, make a living, and generally improve their welfare. Rutashobya (2001) and Makunyi (2017) similarly found that MFI loans assist borrowers in expanding their businesses.

Qualitative findings from FGDs revealed similar results as participants declared that micro loans from MFIs enabled them to expand their businesses and make profits which increased their income as one discussant put it;

..."The money I got has assisted me to expand the chicken project. I am now servicing the loan of 1,000,000/= Tshs and I believe I will keep on expanding..."

Similarly, findings from interviews with loan officers indicated that: borrowers who were engaged in poultry keeping were able to expand their business and consequently increase their income. One Loan officer particularly stated:

“...I am happy that micro loans have increased borrowers' income. In many different ways we provide loans, and by using these loans, they were able to invest, make profit and expand their businesses...". 
Hadija Matimbwa - Theobald Kipilimba, 2018, Vol.2, Issue.6, pp.1-10

Table 4.2: Use of Loans Secured $(n=91)$

\begin{tabular}{lll}
\hline Category & Frequency & Percentage \% \\
\hline Increase my inventory & 46 & $50.4 \%$ \\
Improving the existing business & 45 & $49.6 \%$ \\
\hline Total & $\mathbf{9 1}$ & $\mathbf{1 0 0} \%$ \\
\hline
\end{tabular}

Source: field data (2018)

\subsection{The Household Welfare Situation Before and After Accessing Loans}

The fourth objective was to find out the household situation before and after accessing loans from MFI's. It was revealed that the income of the majority of respondents had significantly increased in comparison to their income prior to joining MFIs. In this aspect, $34 \%$ to $36.2 \%$ had raised their income from 200,000 to 299,000 meaning by contrast, it was an upturn in fortunes as far as loan in financial institutions is concerned.

On the same note though, it should be noted that there are respondents who had a monthly income of 400,000 and above. This is indicative of the fact that accessing MFIs loans is important for raising household income for members who joined MFIs.

Upon securing credit, the household welfare of respondents has relatively improved in comparison to their previous situation. One FGD discussant particularly stated;

....Before taking credit for my business, i faced hard times and I could hardly afford the daily family needs. On top of that, the business was not doing well. But right now, I managed to build my business and I can see changes in family welfare as I have been able to meet almost all their needs...".

Another discussant eagerly added; ..."the loan I took last year has really helped me a lot. I had so many challenges in regards to growth of my business which hampered the welfare of my family. It is now easy to cater for my family needs since the business is doing well..."

Furthermore, $36.4 \%$ of respondents revealed that prior to securing micro loans, they had mud floors whereby $30.7 \%$ indicated that they had un-plastered walls before accessing micro loans, indicating poor living conditions. On the other hand however, $11.3 \%$ of respondents stated that they still had mud floor even after securing loans while $7.6 \%$ still had un-plastered walls. Largely therefore, the living conditions of borrowers significantly improved upon securing loans. Beneficiaries were able to renovate their houses by cementing their floors, had their houses roofed with iron sheets, plastered their house walls and have greater access to basic needs (such as food, shelter and clothing).

\subsection{Conclusion}

Conclusively, the loan repayment capacity of beneficiaries is greatly challenged by the nature of economic activities they engaged in; which are too risky or require time to realise tangible benefits. Other challenges include the high interest rates imposed on loans, which render the instalments higher in comparison to the income generated. In addition, loan beneficiaries are constrained by the weekly and monthly instalment durations. The duration is too short for beneficiaries to comply and therefore leads to loan repayment default and failure to determine attained profit margin from income generating activities. 


\subsection{REFERENCES}

Bayang, S.(2009).Why Microfinance Fails to Meet Enterprise Goals. Retrieved from http://www.allgambian.net/enterprise detail.com.Accessed on 5/5/2018.

Brouwer, W. B. F., VanExel, N. J. A., Vanden, B., VandenBos, G. A. M., \&Koopmanschap, M. A. (2005). Process utility from providing informal care: The benefit of caring. Health Policy 74(1): 85-99.

Chestnut, D (2010). Role of Microfinance Institutions, from the World Wide Web: http://www.ehow.com/about 6744897 role-microfinance-institutions.html. Retrieved March 22, 2018.

Chijoriga, M.M. \& Cassimon, D. (2000).Micro Enterprises Financing - ResentResearch Issues, DUP, Dar es Salaam.

Doocy, S., Norell, D., Teffera, S., \&Burham, G., (2003).Outcome of Ethiopian microfinance programme and management actions to improve services [http://66.102.9.104/search?q=cache:7A8frgTtl20J:www.jhsph.edu/refugee/research/publication/ pdf/Ethiopia.pdf.pdf] site visited on 20 / 1/ 2007.

Kane, S.(2011).Women and Development in Senegal: Microcredit and Household Well Being. 59: 2387-2399.

Kuzilwa, J. A. (2005).The role of credit for Small Business Success: A study of National Entrepreneurship Development Fund in Tanzania.

Littlefield, E., Morduch, J.,\&Hashemi, S. (2003). Focus Note: Is Microfinance an Effective Strategy to Reach the Millennium Development Goal? Washington, D.C. USA.

Microned, R. (2006).Financial sector reforms in Tanzania[http://www.microned.org/microned/coumtries/Tanzania] site visited on 11/2/2008.

Ng'ana, J. J. (2013).The Contribution of Microfinance Institutions in Development of Small Enterprises at Ilala Municipality, Mzumbe University.

Ohri, C. G. (2004).Working papers on microfinance \& Health, A case for Integrated Service Delivery University of Washington, Paper 4:January, 2004 Retrieved September 25, 2010 from the World Wide Web: http://www. Social enterprise. net/pdfs/socent micro health.pdf

Pereira, S.,\&Mourao, P. (2012)."Why does the microcredit borrowing rate differ across countries? A cross-country study", International Journal of Social Economics, Vol. 39 Issue: 8, pp.536-550, https:// doi.org/ 10.1108/ 03068291211238428. Accessed on 11/9/2017.

Roodman, D. (2011). "Due Diligence: An Impertinent Inquiry Into Microfinance." Center for Global Development. 46(2):238-244.

Rubambey, G. (2002). The National Microfinance Policy In: Enhancing Africa's Competitiveness Through Small and Medium Scale Enterprises.(Edited byMatambalya, F. A. \&Mussa, J. A., Mkuki and NyotaPublication,pp 227-334.

Rutashobya,L.(2001). Female Entrepreneurship in Tanzania: Contraints and Strategic Considerations.Proceedings of the International Academy of African Business and Development,Washington,D.C.

Rweyemamu, D. C.,Kimaro, M. P., \&Urassa, O. M. (2003).“Assessing Micro -Finance Services in Agricultural Sector Development:A Case Study of Semi-Formal Financial Institutions in Tanzania" Economic and Social Research Foundation. 
Tsuchiya, A., Miguel, L. S., Edlin, R., Wailoo, A.,\& Dolan,P. (2005).Procedural Justice in Public Healthcare Resource Allocation. Applied Health Economics and Health Policy 4(2): 119-128.

UNDP.(2003).Microfinance

[http://www.undp.org/eo/documents/Essential-onmicrofinance.pdf] site visited 15/ 06 / 2006.

Yunus, M. (2001).Banker to the Poor:The Autobiography of Mohamed Yunus, Founder of Grameen Bank, Dhaka, Bangladesh.The University Press Limited.

Yunus, M. (2010).Building Social Business: The New Kind of Capitalism that Serves Humanity's Most Pressing Needs.New York: Public Affairs. 